\title{
Biomass Carbon Materials Derived from Starch and their Electrochemical Properties
}

\author{
Yawen Hu, Xin Li, Guoying Wang, Fenfang Luo, Kaiqiang Yi, Yves Iradukunda, Gaofeng Shi ${ }^{*}$ \\ School of Petrochemical Engineering, Lanzhou University of Technology, Lan gong ping Road, \\ Lanzhou, Gansu, China \\ *E-mail: $1063623387 @$ qq.com
}

doi: $10.20964 / 2021.03 .05$

Received: 30 September 2020 / Accepted: 17 November 2020 / Published: 31 January 2021

\begin{abstract}
Porous carbon was prepared by using starch as a carbon source and $\mathrm{ZnCl}_{2}$ as an activator. The physical and chemical properties of porous carbon materials were characterized by scanning electron microscope (SEM), transmission electron microscope (TEM), X-ray diffraction (XRD), Raman spectroscopy, Nitrogen adsorption/desorption, and XPS. Nitrogen adsorption/desorption tests show that $\mathrm{ZnCl}_{2}$ has well pore expansion, with a maximum specific surface area of $1591.83 \mathrm{~m}^{2} / \mathrm{g}$ and a total pore volume of 0.89 $\mathrm{cm}^{3} / \mathrm{g}$. Under the $1 \mathrm{~A} / \mathrm{g}$ current density, the specific capacitance is $249 \mathrm{~F} / \mathrm{g}$. When the current density gains from $1 \mathrm{~A} / \mathrm{g}$ to $10 \mathrm{~A} / \mathrm{g}$, the capacitance retention reaches $72.29 \%$. At the same time, it demonstrates high energy density $(34.34 \mathrm{~W} \cdot \mathrm{h} / \mathrm{g})$ and power density $(500 \mathrm{~W} \cdot \mathrm{K} / \mathrm{g})$. The capacitance retention is $90.4 \%$ after 5000 cycles at $2 \mathrm{~A} / \mathrm{g}$ current density. The results depict that the porous carbon is not only an ideal electrode material for supercapacitors but also a good carrier for the preparation of catalysts from mesoporous materials.
\end{abstract}

Keywords: starch, porous carbon, electrochemical performance, supercapacitor

\section{FULL TEXT}

(C) 2021 The Authors. Published by ESG (www.electrochemsci.org). This article is an open access article distributed under the terms and conditions of the Creative Commons Attribution license (http://creativecommons.org/licenses/by/4.0/). 